\title{
NIEUWE GEGEVENS OVER MR. DIRCK VAN CLOON.
}

DOOR

\author{
Dr. F. W. STAPEL.
}

(Met 1 plaat.)

In alle mij bekende levensbeschrijvingen van $\mathrm{Mr}$. Dirck van Cloon, Gouverneur-Generaal van Nederlandsch-Indië, laat men hem zijn carrière aanvangen wanneer hij 4 November 1719 op het schip 't Huys te Assenburgh als opperkoopman naar Indië vaart ${ }^{1}$ ). Dat hij toen reeds een Indische loopbaan achter den rug had, is tot geen der onderzoekers doorgedrongen, hoewel Van Rhede van der Kloot in zijn bekende werk over de Gouverneurs-Generaal wel op het goede spoor moet zijn geweest; hij merkt althans op, dat er enkele jaren vroeger nòg een Dirck van Cloon in Indië had gediend. Maar tot een onderzoek naar de eventueele identiteit van dit tweetal heeft die opmerking hem niet geleid. $\mathrm{Nu}$ zijn er eenige zeer behoorlijke verontschuldigingen voor dit verzuim. Primo is de eerste staat van dienst zóó weinig eervol geëindigd, dat men het daarom al uitgesloten moest achten met een toekomstigen Gouverneur-Generaal te doen te hebben. Secundo is Van Cloon zelf mede debet aan het in vergetelheid raken van dien eersten diensttijd, doordat hij in de „Gequalificeerden Rolle”, een stamboek van de hoogere ambtenaren, om begrijpelijke redenen zijn loopbaan eerst in 1719 laat beginnen. Een recent onderzoek in het oud-koloniaal archief, met name in de resolutiën en missiven van Heeren-XVII en die van Gouverneur-Generaal en Rade, leidde tot de verrassende ontdekking, die ons in de gelegenheid stelt thans voor het eerst een meer volledige biografie van Van Cloon te geven.

Dirck van Cloon werd in 1684 te Batavia geboren als zoon van Philip Jacob van Cloon, oud-burgemeester van Schiedam en later

1) Zie Van Rhede van der Kloot, De Gouverneurs-Generaal van NederlandschIndië; Van der Aa, Biographisch Woordenboek der Nederlanden; Molhuysen en Blok, Nieuw Nederlandsch Biografisch Woordenboek, deel VI (dit in 1923 geschreven artikel is van schrijver dezes); Kok, Vaderlandsch Woordenboek; du Bois, Vies des Gouverneurs-Généraux. 
schepen van Batavia. Reeds op jeugdigen leeftijd zond zijn vader hem voor zijn opvoeding naar Nederland, waar hij te Leiden in de Rechten studeerde. Het Album Studiosorum Academiae LugdunoBatavae omschrijft hem op 25 Maart 1705 als Theodorus van Cloon, Indo-Batavus, oud 20 jaar, jurist. (De doopnaam Dirck wordt in het album meermalen gelatiniseerd tot Theodorus). Kort daarop moet hij zijn gepromoveerd en in 1706 vaart hij op het schip Donckervliet uit naar Indië in den rang van onderkoopman. $\mathrm{Na}$ een verblijf van enkele maanden op Batavia, waar hij geen dienst deed, zendt de regeering hem naar de kust van Cormandel. Achtereenvolgens was hij daar werkzaam als factuurhouder op de hoofdplaats Negapatnat, als kassier aldaar (sedert 1711) en ten slotte, van 1715 af, als opperhoofd van het kantoor Sadraspatnam, een van de belangrijkste inkoopplaatsen der bekende Cormandelsche „lywaten”. Sedert eenige jaren hadden Heeren-XVII den aankoop gelast van ,ruwe”, dat zijn ongekleurde, lijnwaden of katoenen doeken, die dan in ,de vaderlandse kattoendrukkeryen" werden bewerkt. Maar al enkele malen hadden zij moeten klagen over de minderwaardige kwaliteit dier lijnwaden en de Indische regeering had die klachten doorgezonden aan den gouverneur en directeur van de Cormandelsche kust, Adriaen de Visser en zijn raad. Zooals dat in Indië - en ook wel elders gebruikelijk was, zag De Visser weer om naar een zondebok onder zijn onderhoorigen en liet de keus vallen op het personeel van de loge te Sadraspatnam. Hij beschuldigde Van Cloon en zijn medewerkers van den aankoop van ,gansch slegte en ondeugende lywaten, soo dat nauwlijks de helft daarvan voor d'Ed. Compagnie heeft konnen werden aangenomen ofte behouden". Gelijk met deze beschuldiging zond hij Van Cloon, diens secunde of plaatsvervanger, benevens den kassier, van hun ambten ontheven, den 3den Maart 1717 naar Batavia, om zich te verantwoorden. Van Cloon benutte de reis om een verweerschrift op te stellen, dat hij bij ankomst aan de regeering ter hand stelde. Gouverneur-Generaal Christoffel van Swol zond zoowel de beschuldiging als het verdedigingsschrift met ,diverse geannexeerde bylagen" aan de leden van den Raad van Indië ter inzage en bracht den 1sten Juni daarop de kwestie in behandeling. De meerderheid bleek overtuigd, dat de Sadraspatnamsche dienaren zich aan fraude hadden schuldig gemaakt en zich zouden hebben laten omkoopen, zoodat dit eigenlijk een zaak was, die door den Raad van Justitie moest worden berecht. Maar.... bewijzen had men niet en de heeren vreesden dat „om de tegenseggelijkheyt der saeken van 
die natuur en de bysondere uytvlugten, die daarop connen vallen", een rechtsgeding wel eens tot vrijspraak zou kunnen leiden. En dit zou dan weer voor andere knoeiers een aanmoediging zijn om met hun „morseryen” rustig door te gaan. Mitsdien oordeelde men het verstandiger om de zaak administratief af te doen en besloot nog dienzelfden 1sten Juni ,den gemelten Van Cloon in dien staat, waarin hy van Cormandel herwaard is overgekomen, namentlijck buyten dienst en gagie, met de naaste retourschepen als een ontrouw en onnut dienaer te doen vertrecken na het vaderland". Hetzelfde lot viel den secunde en den kassier ten deel.

Wij zeiden niet te veel toen wij er op wezen dat Van Cloon's eerste Indische periode op weinig eervolle wijze werd afgesloten. Maar het slachtoffer was niet van plan het er bij te laten. Hij achtte zichzelf vrij van het aannemen van onwettige emolumenten, maar hij had op dit gebied wel het een en ander gezien. Bovendien oordeelde hij de door hem gekochte lijnwaden van zeer goede kwaliteit; waren ze misschien na aflevering op het hoofdkantoor omgeruild? Hij wendde zich tot Heeren-XVII met een verzoekschrift, dat hij mondeling mocht toelichten en waarbij enkele voor gouverneur De Visser minder aangename dingen ter sprake kwamen. Het gelukte hem de heeren van zijn onschuld, maar bovendien van zijn deskundigheid, te overtuigen en in hun missive van 11 Maart 1719 schrijven zij na onderzoek tot de overtuiging te zijn gekomen, dat de achteruitgang van den lijnwadenhandel in de eerste plaats is veroorzaakt ,,door de kwade directie van den gouverneur De Visser, die wij niet konnen vinden eenige reden gehad te hebben om het gansche comptoir van Sadraspatnam te verstoren en particulierlijk mede niet om het geweese opperhooft Dirk van Cloon van daar te doen opkomen en na Batavia te verzenden". Zij voegen daar aan toe, dat het hun niet mogelijk is geweest andere lieden te vinden die op het gebied van den Cormandelschen handel bekwamer zijn en ,hetselve met meerder promptitude zouden konnen uytvoeren". Daarom hadden zij besloten

$1^{\circ}$ Adriaen de Visser te ontslaan en naar het vaderland op te roepen, en

$2^{\circ}$ Van Cloon in zijn eer te herstellen en hem opnieuw naar Indië te zenden in den hoogen rang van opperkoopman.

Zoo begint dan het tweede, zeer eervolle gedeelte van Mr. Van Cloon's Indische carrière. Zooals wij reeds zeiden, vertrok hij 4 No- 
vember 1719 met 't Huys te Assenburgh naar Batavia. Daar kwam hij 18 Juni 1720 aan en per eerste gelegenheid zond de regeering hem naar Cormandel, waar hij drie jaar werkzaam bleef als secunde van den nieuwen gouverneur, Gerard van Westreenen. Toen werd hij, in 1723, zelf gouverneur en kreeg het jaar daarop rang en titel van buitengewoon Raad van Indië. Tot 1729 bleef hij het bestuur over Cormandel voeren; in dat jaar riep de regeering hem ,ter assistentie aan de regeeringstafel" naar Batavia op. Hij was er nog geen jaar toen hij bericht kreeg van zijn benoeming tot Raad-ordinaris. En in hun brief van 9 October 1731, waarin de Zeventien den Gouverneur-Generaal Mr. Diederick Durven en een aantal andere autoriteiten wegens geknoei oneervol ontslag verleenden, wezen zij Van Cloon als opvolger aan. Hij aanvaardde het hoogste gezag op 28 Mei 1732, maar reeds den 20sten December van het volgende jaar zag hij zich genoodzaakt eervol ontslag te vragen om gezondheidsredenen. Nog voor daarop een beslissing binnenkwam, was hij den 10den Maart 1735 op zijn landhuis aan het Molenvliet te Batavia ,in den Heere ontslaapen". 


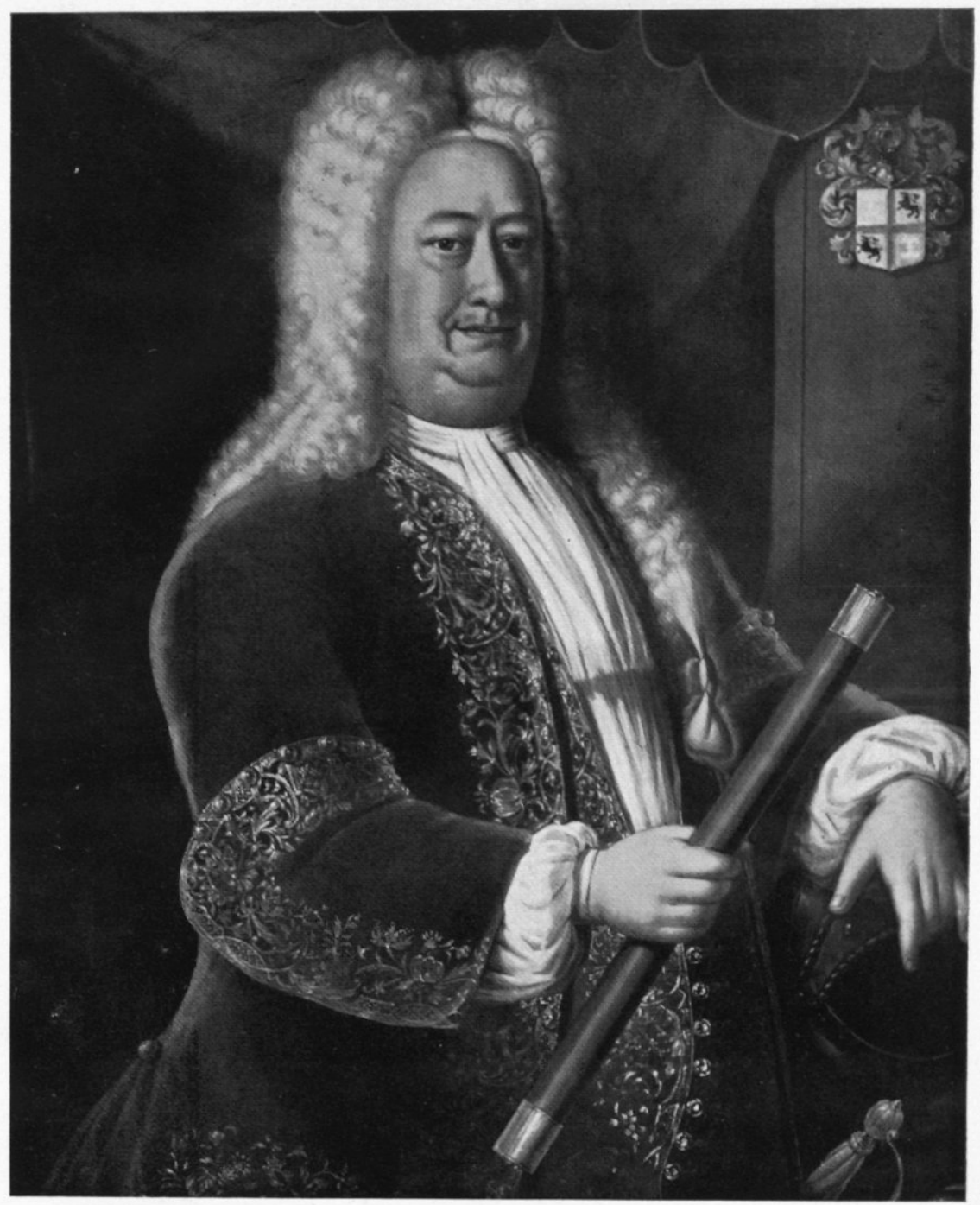

Mr. Dirck van Cloon, Gouverneur-Generaal 1732-1735. 